\title{
FUNKCJONALNOŚĆ WITRYN INTERNETOWYCH MIAST I GMIN W ZARZAZDZANIU KOMUNIKACJĄ Z OTOCZENIEM. ANALIZA WYBRANYCH ELEMENTÓW (NA PODSTAWIE SAMORZĄDÓW Z WOJEWÓDZTWA ŚWIĘTOKRZYSKIEGO)
}

\author{
Abstract \\ Functionality of Websites of Cities and Communities \\ in the Management of Communication with the Environment. \\ Analysis of Selected Elements (Based on Local Self-governments \\ of Świętokrzyskie Voivodship)
}

Governance today requires the activity of local government units in the building of functional communication with the environment of municipalities. The standard is the creation by local authorities websites and the use of information technology. The article presents the results of research on the use and functionality of some online tools used by commons of the Świętokrzyskie voivodeship. Compared the results of two periods - 2010 and 2015.

Keywords: local government, community office, Internet, website, web functionality

\section{Streszczenie}

Zarządzanie sprawami publicznymi wymaga dzisiaj aktywności jednostek samorządowych $\mathrm{w}$ budowaniu funkcjonalnej komunikacji $\mathrm{z}$ otoczeniem gminy. Powszechne jest tworzenie przez urzędy witryn internetowych oraz stosowanie technologii informacyjnych. W artykule przedstawiono wyniki badań dotyczących wykorzystania oraz funkcjonalności wybranych narzędzi online stosowanych przez gminy województwa świętokrzyskiego. Porównano wyniki z dwóch okresów - z 2010 oraz 2015 roku.

Słowa kluczowe: samorząd, urząd, internet, strona www, funkcjonalność serwisu 
Internet zmienia sposoby komunikowania się instytucji i organizacji ze swoim otoczeniem. Pojawianie się nowych narzędzi umożliwiających nawiązanie interakcji przemienia nadawców w odbiorców i odbiorców w nadawców. Zarazem proces przepływu informacji nie jest ograniczony czasem ani zasięgiem, gdyż w komunikacji internetowej trudno jest mówić o cykliczności oraz ograniczeniach w dotarciu do przekazu.

Zmieniające się kanały dostępu do globalnej sieci kształtują nowe wyzwania dla komunikacji instytucji publicznych. Interakcja z otoczeniem, spójność wykorzystania współczesnych technologii informacyjnych stają się istotnymi elementami zarządzania organizacją. Dotyczy to zwłaszcza samorządów lokalnych, w których wymiana informacji między urzędem i otoczeniem stanowi podstawę do podejmowania decyzji w sprawach wspólnoty. Interakcja wykorzystująca komunikację internetową pozwala na szybkie korygowanie działań instytucji, korektę procedur.

Autor artykułu koncentruje swoją uwagę na ocenie wykorzystania przez świętokrzyskie samorządy internetowych narzędzi komunikacyjnych. Prezentuje wyniki badań własnych dotyczących użyteczności informacyjnej i funkcjonalności serwisów samorządów gminnych. Diagnozuje rozwój komunikacji online, opierając swoje wnioski na porównaniu danych pochodzących z 2010 oraz 2015 roku. Wykorzystuje również analizy i raporty dotyczące stosowania przez administrację internetowych form komunikacji. Zarządzanie instytucją publiczną powinno uwzględniać potrzeby informacyjne uczestników przekazu, wykorzystywać trendy pojawiające się w środowisku internetowym, co może stanowić o sukcesie organizacji. Dlatego istotne jest badanie sposobów komunikowania się samorządów korzystających z nowoczesnych technologii. Wyniki pozwalają na określenie kierunków zmian w zarządzaniu informacją oraz pojawiających się trendów w organizowaniu przekazu gmin.

Możliwość uczestniczenia w komunikacji - interakcji nie jest obecnie kwestią trudności (jako nadawca lub odbiorca) w korzystaniu z odpowiedniego sprzętu („twarde bariery”: dostęp do komputera, smartfona itp.), kosztów połączeń i urządzeń (zakupu sprzętu i dostępu do sieci internetowej stacjonarnie, mobilnie) lub włączenia się do sieci (kablowej, bezprzewodowej, komórkowej). Świadczą o tym dane Diagnozy Społecznej, cyklicznego badania dotyczącego warunków i jakości życia Polaków. W 2015 roku komputery są już w 72\% gospodarstw domowych [Batorski, 2015: 355]. Tylko 5\% deklaruje w badaniu, że sytuacja finansowa nie pozwala na korzystanie z internetu.

Przede wszystkim szybko zmienia się struktura dostępu do internetu. W ostatnich latach łącza kablowe tracą, na korzyść dostępu do globalnych zasobów poprzez sieć komórkową [zob. wykres 7.1.2, Batorski, 2015: 356]. Procentowo 90,4\% Polaków ma telefony komórkowe, z czego połowa smartfony, a 27\% internautów (czyli 17,4\% Polaków) wykorzystuje transfer danych w swojej sieci komórkowej, czyli jedna czwarta Polaków ma internet zawsze pod ręką (dane dotyczące smartfonów mogą być niedoszacowane) [Batorski, 2015: 360]. Wraz ze zmianą dostępności do sieci w polskich gospodarstwach domowych wzrasta liczba komputerów przenośnych (49,3\%, stacjonarne 46,9\%). 
Tablety są już w co czwartym domu [Batorski, 2015: 355], a tylko 3\% tych gospodarstw nie ma komputera.

\section{Komunikacja społeczna jako narzędzie w zarządzaniu samorządem}

W środowisku kształtowanym determinizmem technologicznym organizacje oraz instytucje powinny dostosować przekaz do komunikacyjnych tendencji. Szczególnym przypadkiem są serwisy administracji publicznej, zwłaszcza samorządowej. Od władz jednostek samorządu terytorialnego (zwanych dalej JST) wymaga się wykonywania wielu ustawowych zadań z zakresu zarządzania jednostką (rozumianą jako wspólnota) poprzez włączanie mieszkańców, otoczenia biznesowego (i szeroko pojęte otoczenie gminy, jak inne JST lub ewentualni goście, turyści itp.) do procesów decyzyjnych - deliberacji i partycypacji dla dobra „małej ojczyzny”. Do sprawnego zarządzania strumieniem informacji niezbędna jest nowoczesna komunikacja oparta na technologiach informacyjno-komunikacyjnych (zwanych dalej TIK). Dla administracji to wyzwanie ze względu na dynamiczne zmiany ekonomiczne, społeczne w otoczeniu JST, ale przede wszystkim technologiczne, które wymuszają nowe podejście do budowania strategii zarządzania komunikacją społeczną. Stąd pojawiające się koncepcje nowoczesnego („nieweberowskiego”) podejścia do zarządzania zasobami instytucji publicznej, dotyczące wiedzy oraz informacji, jak chociażby New Public Management lub Good Governance'.

Samorządy mają swoją specyfikę zasobów wykorzystywanych w procesie zarządzania wspólnotą, a jednym $\mathrm{z}$ istotnych elementów jest miejsce w lokalnej społeczności jako głównego źródła informacji [Supernat, 2002: 400-403]. Dlatego pojawia się potrzeba stworzenia skutecznej polityki komunikacji społecznej opartej na systematycznych i planowych działaniach JST. Konieczność zarządzania informacją jest istotna dla tworzenia spójnej wymiany informacji między władzą a otoczeniem gminy, ale zarazem dla otrzymywania informacji zwrotnej w celu korygowania decyzji lub procedur. W okresie dynamicznych zmian w TIK niezbędne jest dostosowanie się do trendów, wymagających nowego podejścia do zarządzania wiedzą i informacją, zwłaszcza w zakresie marketingu. Umiejętne wykorzystanie technologii komunikacyjnych, zarządzania narzędziami i przekazem może stanowić o sukcesie samorządu [Strzelecki, 2008: 40]. Nowe technologie pozwalają na tworzenie systemu wymiany informacji, który możemy nazwać „partnerstwem komunikacyjnym”. Współcześnie uczestnicy procesu komunikowania mogą łatwo zamieniać się rolami - wchodzić w interakcje. Zanika dominująca pozycja nadawcy, publiczność zaś (widz, słuchacz, internauta, czytelnik,

\footnotetext{
${ }^{1}$ Autor, ze względu na obszerność tematyczną przywołanych koncepcji, nie będzie ich rozwijał, gdyż nie stanowią głównego problemu prezentowanego w artykule.
} 
w zależności od kanału komunikacji) staje się jednocześnie twórcą treści (co stanowi fundament komunikacji Web 2.0). Daje to podstawy do łatwego uczestniczenia w wymianie informacji, a także uzyskiwania wiedzy o społecznych nastrojach [Sakowicz, 2007: 125].

Internetowy serwis gminy stanowi obecnie niezwykle rozległą platformę wymiany informacji, a zarazem pełni funkcję agregatora wiedzy o JST. Może przyjmować zróżnicowane formy: od prostej strony www, odgrywającej jedynie rolę informatora biuletynu, po rozbudowane serwisy z wieloma aplikacjami umożliwiającymi prowadzenie komunikacji z wykorzystaniem urządzeń mobilnych.

Można wyróżnić dwie podstawowe kategorie internetowego kontaktu gminy $\mathrm{z}$ otoczeniem. Pierwszy to ten narzucony przepisami ustawy o dostępie do informacji publicznej; samorządy mają obowiązek prowadzenia Biuletynu Informacji Publicznej (dalej BIP). Drugim rodzajem kontaktu jest oficjalna strona www z linkami do BIP oraz innymi serwisami i usługami oferowanymi przez samorząd.

Na gminy zostało nałożonych wiele zadań publicznych. Jednymi z najważniejszych są: wywiązywanie się z obowiązku prowadzenia BIP² $^{2}$ oraz wprowadzanie szeroko rozumianych usług e-administracji ${ }^{3}$. Redakcja treści i przekazu w BIP jest dokonywana zgodnie z wymogami rozporządzenia ministra ${ }^{4}$. Zawiera zbiór podstawowych danych dotyczących samorządu: władz urzędu, radnych i dokumentów, których publikacja jest obowiązkowa. Gminy ${ }^{5}$ nierzadko jednak lekceważą wymogi prawne, nie zamieszczając na bieżąco informacji o zmianach w urzędzie lub uchwał radnych. Elementem zniechęcającym do korzystania z BIP jest przede wszystkim forma przekazu. Zamieszczane oficjalne treści, urzędowy język i uboga szata graficzna powodują, że tego rodzaju biuletyny nie są atrakcyjnymi stronami dla internautów.

Samorządy jednak znacznie rozszerzają możliwości swoich serwisów, ale tych poza BIP, które nie podlegają przepisom o informacji publicznej. W Polsce na 2478 gmin w 2014 roku jedynie 15 nie posiadało własnej witryny [Kowalik, 2015b: 13]. Serwisy te mogą być dla internautów istotnym źródłem informacji. Według badań Ministerstwa Administracji i Cyfryzacji (dane dotyczą instytucji publicznych, brak wyników dotyczących wyłącznie JST) 78\% korzystających

2 Dostęp do informacji publicznej regulują dwa podstawowe dokumenty: Ustawa z dnia 6 września 2001 r. o dostępie do informacji publicznej, Dz.U. $2001 \mathrm{Nr} 112$ poz. 1198; oraz Ustawa z dnia 16 września 2011 r. o zmianie ustawy o dostępie do informacji publicznej oraz niektórych innych ustaw, Dz.U. 2011 Nr 204 poz. 1195, Dz.U. 012 poz. 473; a także Rozporządzenie Ministra Spraw Wewnętrznych i Administracji z dnia 18 stycznia 2007 r. w sprawie Biuletynu Informacji Publicznej, Dz.U. 2007 Nr 10 poz. 68.

${ }^{3}$ E-government, czyli „korzystanie z narzędzi i systemów informatycznych w celu zapewnienia lepszej jakości usług publicznych dla obywateli i przedsiębiorstw" jako wprowadzania licznych usług dla obywateli, przedsiębiorców, umożliwiających przeprowadzenie procedur administracyjnych poprzez aplikacje internetowe. E-government, https://ec.europa.eu/digital-single-market/en/ glossary\#e [dostęp: 1.02.2016].

${ }^{4}$ Zob. przyp. 2.

${ }_{5}^{5}$ Autor będzie dalej odnosił się jedynie do samorządów gmin miejskich (i miast na prawach powiatu), miejsko-wiejskich i wiejskich, gdyż gospodarze tych jednostek wybierani są w wyborach bezpośrednich. Marszałkowie i starostowie nie pochodzą z wyborów bezpośrednich. 
z internetu często przegląda serwisy w celu ,pozyskania danych adresowych, kontaktowych, o godzinach funkcjonowania instytucji”, 68\% chce się dowiedzieć „jak załatwić sprawę”, a 58\% - do ,znalezienia informacji o prawach i obowiązkach wynikających z przepisów prawa" [E-administracja..., 2014: 13]. Stąd coraz istotniejszym elementem funkcjonowania JST jest użyteczność urzędowych serwisów (web usability).

\section{Rola funkcjonalności serwisu internetowego}

Jakob Nielsen, który opracował pierwsze podstawy web usability, zdefiniował użyteczność jako atrybut jakości oceniający łatwość wykorzystania interfejsu przez użytkownika. Na atrybut ten składa się pięć komponentów [Nielsen, 2016a]:

- learnability - możliwość szybkiego uczenia się, jak łatwo użytkownik podczas pierwszego kontaktu z serwisem może wykonać podstawowe zadania?

- efficiency - sprawność - jak szybko internauci mogą wykonywać zadania, gdy już zapoznali się z serwisem?

- memorability - zapamiętywalność - jak łatwo użytkownicy mogą osiągnąć biegłość w korzystaniu po dłuższej nieobecności w serwisie?

- errors - błędy - ile błędów użytkownicy dokonują, jak poważne są te błędy i jak łatwo można sobie z nimi poradzić?

- satisfaction - satysfakcja - jak atrakcyjne jest korzystanie z serwisu?

Użyteczność i funkcjonalność w języku polskim mają zbliżone znaczenie, stąd pojawiają się rozbieżności w definiowaniu obu terminów oraz interpretacja komponentów Nielsena. Dla niniejszego badania przyjęto, że „»funkcjonalność« to zakres dostępnych funkcji (jeśli ktoś mówi »dodaliśmy nową fukcjonalność«, wiadomo, że poszerzono zakres), zaś »użyteczność« to łatwość obsługi i dopasowanie do rzeczywistych potrzeb użytkownika (»polepszyliśmy użyteczność produktu«, czyli poprawiliśmy własności użytkowe, zwłaszcza łatwość obsługi i - domyślnie - zwiększyliśmy też poziom zadowolenia użytkowników" [Sikorski, 2016].

Definicja ta była budowana pod kątem serwisów komercyjnych, ale ogólne założenia Nielsena można stosować również w badaniu użyteczności portali instytucji publicznych. Należy jednak brać pod uwagę specyfikę komunikacji samorządowej, w której nie ma konieczności realizacji celów komercyjnych. Konwersję ${ }^{6} \mathrm{w}$ przypadku tego rodzaju serwisów należy rozumieć jako podjęcie działań typu: nawiązanie interakcji (skutecznej dwustronnej komunikacji za pomocą np. e-maila, komunikatora, lub wielostronnej, np. poprzez portal społecznościowy, forum), rozpoczęcie ścieżki administracyjnej (np. dostęp do adresu koresponden-

${ }^{6}$ Konwersja to podjęcie przez użytkownika działania pożądanego przez właściciela serwisu internetowego. Zob. Konwersja-definicja, 2016. 
cyjnego), otrzymanie informacji o działalności gminy, miasta itd. (przez klienta urzędu - mieszkańca lub gościa gminy, np. turysty, inwestora). Użyteczność serwisów gminnych jako ,produktu” dla klienta powinna wspierać realizację potrzeb użytkownika i dążyć do uzyskania jego satysfakcji. Temu służy stworzenie witryny z narzędziami online umożliwiającymi wskazaną interakcję. Funkcjonalność witryn gminnych należy odnieść do działania poszczególnych elementów. Jeżeli „produkt” ma adres e-mail i komunikator, to możliwość wyboru adresata (prezydent, radny itp.) zwiększa funkcjonalność. Podobnie jak dział aktualności: samo jego opublikowanie nie poszerza zakresu funkcji informacyjnej, jeżeli nie są zamieszczane w nim bieżące informacje.

Badania serwisów takich instytucji jak gminne urzędy (szerzej administracja publiczna) nabierają szczególnego znaczenia zwłaszcza w kontekście badań Diagnozy Spotecznej. Niepokojące są dane nie te dotyczące posiadania przez Polaków dostępu do sieci, ale te świadczące o niedostatecznym zainteresowaniu jej wykorzystywania. Autorzy badania wskazują na brak motywacji do surfowania, wiedzy, jak można zdobyte informacje efektywnie wdrożyć do codziennego życia oraz brak umiejętności w korzystaniu z TIK [Batorski, 2015: 362-363]. Istotne znaczenie mają również wiek, wykształcenie i miejsce zamieszkania. W tym przypadku ważnym parametrem jest dostępność do serwisów, czyli web accessibility. Należy podkreślić, że dostępność serwisów publicznych doczekała się oficjalnych zaleceń, które urzędy mają obowiązek wprowadzać, użyteczność zaś (web usability) takich nie posiada [zob. szerzej: Kowalik, 2015].

Potrzebę analizy użyteczności i funkcjonalności potwierdzają badania Ministerstwa Administracji i Cyfryzacji (obecnie Ministerstwo Cyfryzacji). Pytano użytkowników serwisów urzędowych, jak oceniają „łatwość znalezienia potrzebnych informacji”, ,zrozumiałość informacji” oraz „użyteczność informacji". W okresie 3 lat ankietowania we wszystkich kategoriach brak jest wyraźnego polepszenia ocen. W badaniu najgorsze wyniki (średnia ogólnopolska) dotyczyły łatwości znalezienia informacji: jedynie 35\% pytanych „raczej pozytywnie” wypowiedziało się o witrynach, „pozytywnie” 19\% [E-administracja..., 2014: 13]. „Negatywne” oceny wystawiło 3\%, ,raczej negatywne” 12\%. Zrozumiałość informacji oraz ich użyteczność są oceniane jedynie nieznacznie wyżej (różnice od 1 do 4\%).

Województwem, które uzyskało jedne z najniższych ocen, jest świętokrzyskie. Tu 47\% ankietowanych negatywnie oceniło łatwość znalezienia informacji w serwisach urzędowych i instytucji publicznych, $48 \%$ negatywnych wypowiedzi dotyczyło „zrozumiałości informacji”, zaś 58\% ,użyteczności informacji” (w przypadku ,użyteczności informacji” gorszy wynik miało jedynie województwo lubelskie - 57\%) [E-administracja..., 2014: 14].

Samorządy wiejskie, miejsko-wiejskie oraz miejskie starają się budować przekaz medialny z wykorzystaniem coraz szerszej palety narzędzi oferowanych w internecie. Rozwijają swoje serwisy, uzupełniając je o wciąż nowe funkcjonalności, nie tylko te związane z obowiązkami narzuconymi przez administrację centralną, ale również te budujące więzi z otoczeniem: mieszkańcami, gośćmi, biznesem. Wciąż pojawiające się nowe technologie informacyjne pozwalają na poszerzenie 
oferty komunikacyjnej, co wiąże się z ich odpowiednim zastosowaniem, użytecznym i funkcjonalnym dla uczestników już nie tylko jednokierunkowego przekazu informacji, ale przede wszystkim interakcji w globalnej sieci.

\section{Opis metody badawczej}

Celem badania było zdiagnozowanie wybranych elementów funkcjonalności serwisów internetowych oraz interaktywności sieciowej w komunikacji samorządów. Wybrano gminy województwa świętokrzyskiego, gdyż podobne badania przeprowadzono w 2010 roku, co pozwoliło na dokonanie porównań niektórych wyników.

We wrześniu 2015 roku dokonano analizy strony www 102 gmin. Dotyczyła ona wszystkich gmin świętokrzyskich: 5 miast, 26 gmin miejsko-wiejskich i 71 wiejskich?

Przeprowadzono badanie polegające na stworzeniu tak zwanej ,persony”, czyli archetypu osoby mogącej stanowić wzór użytkownika serwisy internetowego. Założono, że będzie to osoba młoda, doświadczona w poruszaniu się po serwisach webowych. W tym celu grupie studentów zlecono przeprowadzenie kilku operacji mających sprawdzić funkcjonowanie serwisów gminnych. Przygotowano także autorską tak zwaną listę kontrolną ${ }^{8}$ wybranych elementów serwisu, która podlegała weryfikacji w trakcie badania (poprawność wyświetlania się serwisu w przeglądarkach; publikowanie adresów wójtów, burmistrzów, prezydentów, radnych, wydziałów urzędów; domeny oficjalnych adresów pocztowych; publikowanie aktualności dotyczących ważnych wydarzeń krajowych). Dokonano również pomiaru reakcji (czasu i liczby odpowiedzi) na korespondencję e-mailową wysłaną do urzędów. Wyniki porównano z badaniem wykonanym w 2010 roku?.

W budowaniu schematu badawczego kierowano się wybranymi elementami zaleceń tak zwanych heurystyk Nielsena [2016b] oraz wskazówek opracowanych przez U.S. Department of Health and Human Service [Nielsen, 2016a].

Hipoteza zakładała, że w okresie 5 lat samorządy gminne zwiększyły użyteczność oraz funkcjonalność serwisów internetowych i polepszyły interakcję z wykorzystaniem narzędzi komunikacji sieciowej ze swoim otoczeniem.

7 W badaniu nie uwzględniano stron internetowych powiatów i samorządów wojewódzkich.

${ }^{8}$ Przykładowy opis metody zob. Inspekcje i listy kontrolne, 2016.

9 Badania przeprowadzone w ramach dysertacji doktorskiej obronionej na Wydziale Dziennikarstwa i Nauk Politycznych Uniwersytetu Warszawskiego [Kowalik, 2010]. 


\section{Wyniki badań}

Oficjalna komunikacja sieciowa samorządu to Biuletyn Informacji Publicznej. Zdaniem autora ten serwis nie jest atrakcyjnym źródłem informacji dla internautów. Layouty stron są często mało czytelne, z nieintuicyjnym układem treści i skomplikowanym układem menu (ścieżkami dostępu do treści). Ich forma jest uboga graficznie, pozbawiona multimediów. Zawierają przede wszystkim informacje dotyczące prawa lokalnego, oferty dla inwestorów, notki dotyczące władz samorządowych. W trakcie prowadzonej obserwacji w 2010 oraz w 2015 roku wszystkie samorządy gminne dysponowały obowiązkowym BIP.

Formuła przekazu BIP daleka jest jednak od atrakcyjności serwisów webowych, z którymi na co dzień ma do czynienia użytkownik Internetu. Jest on przyzwyczajony do otrzymywania treści uzupełnianych wizualnie (grafiki, multimedia itp.) i łatwiejszych w przyswojeniu od języka urzędowego stosowanego w BIP.

Dzisiaj strona internetowa jest standardem i jej brak może wpływać na wizerunek gminy. Dlatego prawie wszystkie gminy starają się stosować taką formę komunikacji z otoczeniem. Pięć lat temu pięć samorządów świętokrzyskich nie dysponowało własnymi serwisami www (posiadały jedynie obowiązkowy BIP, zob. tabela 1). Zaskakujący był fakt, że w obserwacji w 2015 roku wskazano jedną gminę, która nadal nie posiadała strony internetowej.

Serwis webowy nie jest jednak gwarancją skutecznej komunikacji, gdyż w okresie badania w 2010 roku trzy witryny www nie działały prawidłowo (nie udało się wyświetlić zawartości za pomocą trzech przeglądarek internetowych ${ }^{10}$ ). W 2015 roku ta liczba spadła do dwóch. Były to małe gminy wiejskie.

Tabela 1

Porównanie liczby samorządów nieposiadających własnym stron www i stron,

które nie działały w okresie badania

\begin{tabular}{|l|c|c|}
\hline & Rok 2010 & Rok 2015 \\
\hline Liczba gmin bez strony www & 5 & 1 \\
\hline Liczba stron www, które nie działały & 3 & 2 \\
\hline
\end{tabular}

Źródło: badania własne

Serwis internetowy to źródło podstawowych informacji o samorządzie i przede wszystkim funkcjonowaniu samego urzędu. Dlatego istotnym elementem każdego serwisu jest łatwość uzyskania kontaktu z przedstawicielami władz

${ }^{10}$ Dostępność w 2010 roku sprawdzano za pomocą przeglądarek, które miały największą popularność w Polsce (udział w rynku): Firefoxa, Explorera oraz Opery. Do 2015 roku te relacje się zmieniły i wykorzystywano w badaniu Chrome, Firefoxa oraz Explorera. 
gminnych. W zdecydowanej większości witryn brakuje jednak adresów do korespondencji mailowej z gospodarzami gmin, radnymi lub komórkami urzędowej administracji. Podczas badania z 2015 roku te ostatnie były dostępne jedynie na 24 stronach internetowych (zob. tabela 2). Ich liczba pozostała bez zmian od 2010 roku. Nie ma znaczących różnic między rodzajami jednostek samorządowych bez względu na jej wielkość (gmina miejska czy wiejska). Rzadko spotykanym elementem serwisu jest kontakt mailowy z radnymi. Podczas obserwacji w 2010 roku pełne listy z adresami występowały w pięciu witrynach, w 2015 roku liczba ta wzrosła do sześciu. Wyniki wskazują na zmniejszenie możliwości kontaktu mailowego z prezydentami, burmistrzami i wójtami. Liczba adresów poczty elektronicznej spadła blisko o jedną trzecią (z 30 maili w 2010 roku do $21 \mathrm{w}$ roku 2015, zob. tabela 2).

Tabela 2

Porównanie liczby adresów mailowych dostępnych w witrynach samorządowych miast, gmin miejsko-wiejskich i wiejskich

\begin{tabular}{|c|c|c|c|c|c|c|}
\hline \multirow{3}{*}{$\begin{array}{c}\text { Gminne witryny } \\
\text { www }\end{array}$} & \multicolumn{6}{|c|}{ E-maile kontaktowe } \\
\hline & \multicolumn{2}{|c|}{ Gospodarze } & \multicolumn{2}{|c|}{ Radni } & \multicolumn{2}{|c|}{ Wydziały } \\
\hline & 2015 & 2010 & 2015 & 2010 & 2015 & 2010 \\
\hline Miejskie (5) & 2 & 2 & 3 & 2 & 4 & 3 \\
\hline Miejsko-wiejskie (26) & 12 & 9 & 2 & 2 & 9 & 9 \\
\hline Wiejskie (71) & 7 & 19 & 1 & 1 & 11 & 12 \\
\hline Razem & 21 & 30 & 6 & 5 & 24 & 24 \\
\hline Różnica względem 2010 r. & \multicolumn{2}{|c|}{-9} & \multicolumn{2}{|c|}{1} & \multicolumn{2}{|c|}{0} \\
\hline
\end{tabular}

Źródło: badania własne

We wszystkich serwisach występowały ogólne adresy e-mailowe do urzędu, ale efektywność dotarcia do nich, znalezienia w witrynie, była zróżnicowana. Grupie studentów zlecono znalezienie adresu i wskazanie liczby kliknięć na ścieżce dostępowej. Test nawiązywał do tak zwanej reguły trzech kliknięć. Według tej zasady nawigowanie na stronie powinno pozwolić użytkownikowi dotrzeć do pożądanej informacji w maksymalnie trzech krokach ${ }^{11}$. W innym przypadku internauta może zniechęcić się do dalszego korzystania z serwisu. Test stron samorządowych wykazał, że najszybciej można dotrzeć do adresu urzędu w witrynach miejskich, najgorzej zaś prezentują się miejsko-wiejskie (zob. tabela 3). Tego rodzaju testu

${ }^{11}$ Szerzej zob. Robertson, 2015. Zasadność reguły była sprawdzana i nie znalazła potwierdzenia w badaniach. Zob. Porter, 2015. Nadal jednak jest uznawana za uzasadnioną i przydatną w projektowaniu serwisów. 
nie przeprowadzono w 2010 roku, nie ma więc danych porównawczych. Wyniki zostaną wykorzystane w kolejnych badaniach.

Tabela 3

Liczba kliknięć dotycząca znalezienia adresu gminy

\begin{tabular}{|c|c|c|c|c|c|c|c|}
\hline \multirow{2}{*}{ E-mail urzędu gminy } & \multicolumn{6}{|c|}{ Liczba kliknięć } & \multirow{2}{*}{ Średnia 2,4} \\
\hline & 1 & 2 & 3 & 4 & 5 & 6 & \\
\hline Miasta (5) & 2 & 2 & 1 & & & & 1,8 \\
\hline Miejsko-wiejskie (26) & 3 & 9 & 3 & 3 & 6 & 2 & 3,2 \\
\hline Wiejskie (71) & 14 & 41 & 4 & 1 & 4 & 5 & 2,3 \\
\hline
\end{tabular}

Źródło: badania własne

Kolejny etap badania polegał na wysłaniu na urzędową skrzynkę mailową korespondencji i rejestracji interakcji. Samorządowców poproszono o podanie informacji dotyczących podatków gminnych i możliwości ich szybkiej wpłaty. Sprawa wydaje się istotna dla samorządowego budżetu, ale wyniki pomiaru reakcji na e-maile okazały się w części identyczne z tymi sprzed pięciu lat (zob. tabela 4).

Tabela 4

Porównanie liczby odpowiedzi na korespondencję e-mailową

\begin{tabular}{|c|c|c|}
\hline Rok & Liczba odpowiedzi & Średni czas odpowiedzi w dniach \\
\hline 2010 & 54 & 11 \\
\hline 2015 & 55 & 2 \\
\hline
\end{tabular}

Źródło: badania własne

Podczas badania w 2010 roku nadeszły 54 maile, a pięć lat później - jedynie jeden więcej. Znaczna różnica nastąpiła w czasie reakcji na korespondencję, gdyż w 2015 roku średni czas wyniósł dwa dni, w 2010 to było aż 11 dni. W 2015 roku proporcjonalnie najwięcej odpowiedzi udzielono w dniu wysłania e-maila z pytaniem (zob. wykres 1$)^{12}$. To ponad połowa $(53,7 \%)$ zwrotnej korespondencji. W 2010 roku procent tak szybkich odpowiedzi był o połowę mniejszy (wynosił 25,5\%).

12 Założono, że odpowiedzi powinny nadejść w ciągu 14 dni. Dwie ostatnie otrzymano po 26 i 29 dniach od wysłania korespondencji. 


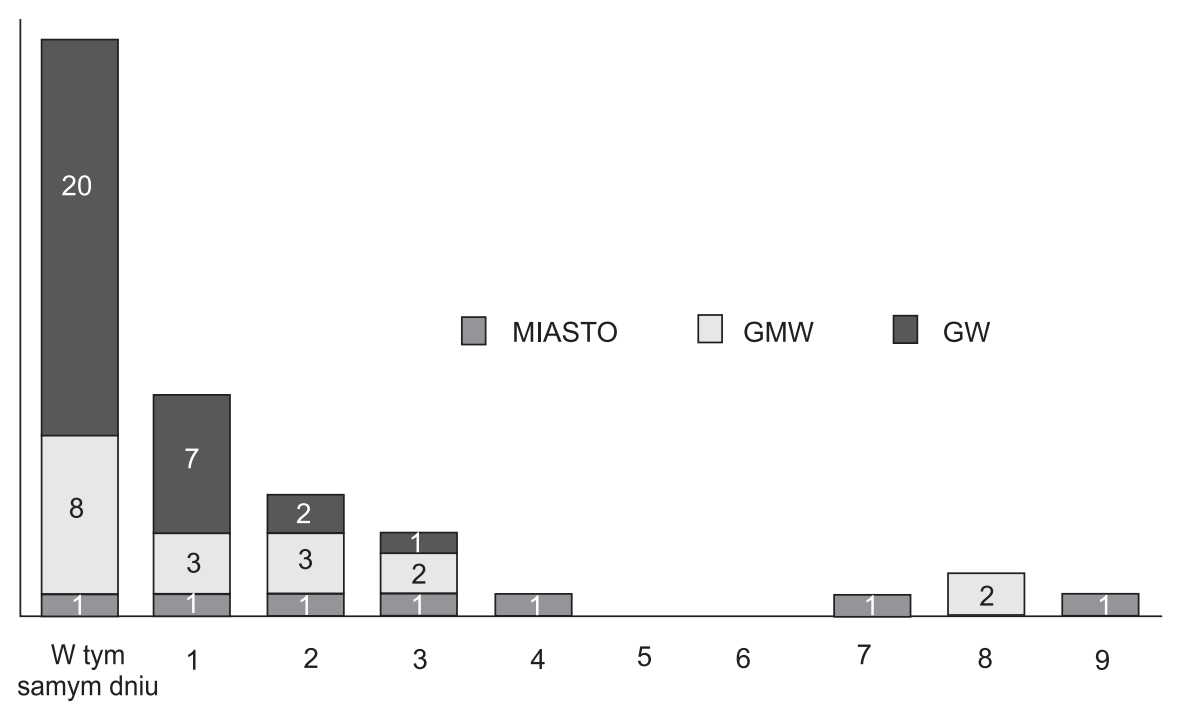

Wykres 1. Liczba odpowiedzi gmin miejskich (MIASTO), miejsko-wiejskich (GMW) i wiejskich (GW) na e-maila w dniu wysłania i w dniach kolejnych w badaniu w 2015 roku

Źródło: badania własne

W trakcie badania w 2010 roku zauważono, że urzędy posługiwały się skrzynkami e-mailowymi zakładanymi poza domeną urzędową. W kolejnym badaniu zaobserwowano podobne zjawisko. W 2010 roku istniały 24 adresy na przykład w domenie o2.pl, interia.pl lub onet.pl. W 2015 roku ta liczba spadła do 16. Najczęściej korzystały z nich gminy wiejskie ( 20 w 2010, 16 w 2015) oraz miejsko-wiejskie (4 w 2010, 5 w 2015). Wszystkie miejskie działały na własnych domenach. Stosowanie skrzynek w bezpłatnych serwisach pociąga za sobą wiele konsekwencji związanych z zaufaniem do urzędu. Korespondencja może zawierać dane osobowe niezbędne do załatwienia sprawy. Serwisy pocztowe zbierają dane dotyczące swoich klientów i wykorzystują je w celach marketingowych.

Istotnym elementem komunikacji jest stosowanie narzędzi pozwalających nie tylko na korespondencję, ale również na wymianę opinii i nawiązanie natychmiastowej oraz ciągłej interakcji. Można do nich zaliczyć przede wszystkim stosowanie komunikatorów, czatów, sond, forum internetowego i serwisów społecznościowych. W trakcie obserwacji witryn samorządowych sprawdzano, czy te narzędzia były używane w 2015 oraz w 2010 roku. Wyniki sprzed pięciu lat wskazują na dużą popularność sond oraz internetowych forów. Blisko jedna piąta (17) gmin prosiła internautów o wyrażenie swojego zdania w sondzie oraz opinii na forum (zob. wykres 2). Rzadziej używano komunikatorów (3), kanałów RSS (6), czatów (3) i serwisów społecznościowych (3).

Badania z 2015 roku wskazują na odwrócenie się proporcji w wykorzystywaniu social mediów i pozostałych narzędzi. Wzrosła obecność urzędów w serwisach społecznościowych. Ponad jedna czwarta gmin $(28,4 \%)$ ma profil w social 
mediach. Najpopularniejszym serwisem jest Facebook (22,5\% gmin ma oficjalny profil). Na pięć świętokrzyskich miast cztery mają profile społecznościowe, z czego trzy na Facebooku. Wśród 26 gmin miejsko-wiejskich te liczby wynoszą odpowiednio 15 i 11, spośród 71 wiejskich odpowiednio 10 i 9. Inne popularne serwisy społecznościowe to YouTube, Vimeo, Nasza Klasa i Twitter. Inne narzędzia sondy, zwłaszcza fora, są coraz rzadziej stosowane. Komunikatory zniknęły z serwisów www, spadła liczba czatów, wzrosła jedynie liczba kanałów RSS.

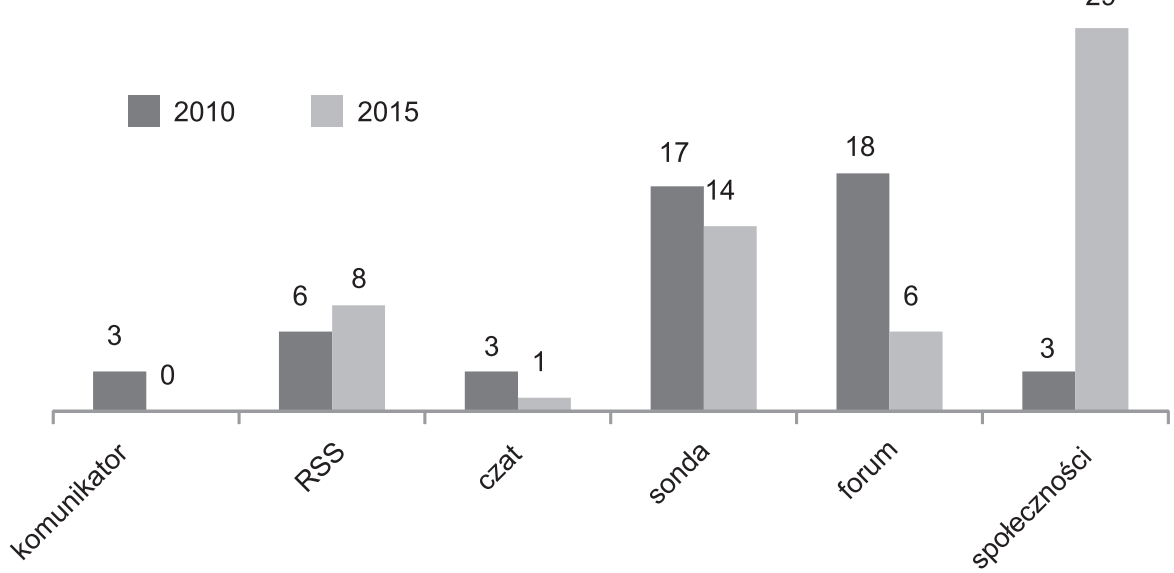

Wykres 2. Porównanie liczb gmin, które w 2010 i 2015 roku udostępniły komunikatory, kanały RSS, czaty, sondy, fora internetowe oraz linki do serwisów społecznościowych

Źródło: badanie własne

Istotnym elementem każdego serwisu samorządowego są aktualności. W wielu witrynach znajdujemy deklaracje, że to „oficjalny serwis informacyjny” lub ,portal informacyjny". Można się więc spodziewać, że internauta znajdzie na nich ważne komunikaty dotyczące nie tylko wydarzeń lokalnych, ale przede wszystkim istotnych krajowych. Podjęto próbę porównania liczby newsów. W badaniu 2010 roku założono, że jednym z najważniejszych bieżących wydarzeń są wybory prezydencie i komunikaty o nich powinny zostać opublikowane w serwisach. W 2015 roku wydarzeniem wyborczym było przeprowadzenie ogólnokrajowego referendum. Informowały o nich media publiczne i komercyjne (ogólnopolskie oraz lokalne). W serwisach samorządowych w 2010 roku w dziale aktualności ukazało się na wskazany temat jedynie osiem informacji, a pięć lat później komunikatów było 49 (zob. tabela 5). Oznacza to wzrost w 2015 roku aż o 513\%.

Istotny wzrost informacji dotyczył nie tylko istotnych wydarzeń, ale również innych wiadomości zamieszczanych w działach aktualności (zob. tabela 5). W 2010 roku średnia tygodniowa liczby informacji wynosiła 255. W 2015 roku w jednym tygodniu badania zanotowano ich 389 . Oznacza to wzrost o $53 \%$ w stosunku do 2010 roku. 
Tabela 5

Liczba informacji dotycząca aktualności i istotnych informacji

\begin{tabular}{|l|c|c|c|}
\hline \multicolumn{1}{|c|}{ Rodzaj informacji } & Rok 2010 & Rok 2015 & Różnica (\%) \\
\hline Aktualności tygodniowo & 255 & 389 & 53 \\
\hline Istotne wydarzenie* & 8 & 49 & 513 \\
\hline
\end{tabular}

* 2010 - wybory prezydenckie

* 2015 - referendum krajowe

Źródło: badanie własne

W przypadku porównania pierwszych pięciu pozycji najliczniej publikujących serwisów, powtarzają się nazwy samorządów już wcześniej przodujących w liczbie aktualności (zob. tabela 6, pozycje powtarzające się wyboldowano). Niektóre z samorządów dokonały znacznych zmian, wprowadzając nowe layouty swoich portali, które organizacją treści przypominają serwisy komercyjne.

Tabela 6

Liderzy w liczbie opublikowanych informacji w dziale aktualności, porównanie w latach 2010 i 2015

\begin{tabular}{|c|c|c|c|c|c|}
\hline \multicolumn{2}{|c|}{ Miejskie } & \multicolumn{2}{c|}{ Miejsko-wiejskie } & \multicolumn{2}{c|}{ Wiejskie } \\
\hline $\mathbf{2 0 1 0}$ & $\mathbf{2 0 1 5}$ & $\mathbf{2 0 1 0}$ & $\mathbf{2 0 1 5}$ & $\mathbf{2 0 1 0}$ & $\mathbf{2 0 1 5}$ \\
\hline Kielce & Starachowice & Chęciny & Włoszczowa & Pawłów & Masłów \\
\hline Ostrowiec Św. & Sandomierz & Połaniec & Ożarów & Zagnańsk & Morawica \\
\hline Starachowice & Kielce & Włoszczowa & Pińczów & Złota & Pawłów \\
\hline Sandomierz & Ostrowiec Św. & Pińczów & Chęciny & Brody & Zagnańsk \\
\hline Skarżysko Kam. & Skarżysko-Kam. & Małogoszcz & Staszów & Piekoszów & Krasocin \\
\hline
\end{tabular}

Źródło: badanie własne.

\section{Wnioski}

Wyniki badań wskazały, że pomimo upływu pięciu lat nie wszystkie samorządy widzą potrzebę tworzenia własnej rozbudowanej i funkcjonalnej strony www. Nadal władze jednej gminy posługują się wyłącznie obowiązkowym BIP. Niepokojący jest jednak fakt wciąż utrudnionego kontaktu z urzędem i władzą wykonawczą, wynikający z braków standardowego dzisiaj kanału komunikacji, jakim jest e-mail. Można mówić o znacznym zmniejszeniu wartości użytkowych serwisu poprzez spadek liczby opublikowanych elektronicznych skrzynek 
pocztowych gospodarzy samorządów. Zmniejszyła się blisko o jedną trzecią, natomiast wzrost kompletów adresów e-maili do radnych (o jeden) można potraktować w kategoriach symbolicznych. Okazuje się również, że ścieżki dostępowe do adresów (,reguła trzech kliknięć”) nie ułatwiają nawiązania korespondencji. Rejestracja reakcji na wysłane e-maile wykazała, że nie ma istotnego wzrostu aktywności samorządowców na rozesłaną korespondencję: w 2015 roku nadeszła tylko jedna odpowiedź więcej. Zauważalny jest natomiast znaczny wzrost szybkości odpowiedzi na e-maile, co zwiększa satysfakcję użytkownika serwisu. $Z$ jednej strony może to świadczyć o rosnącej świadomości ważności tego kanału komunikacji. Z drugiej nadal niepokojący jest fakt wykorzystywania przez urzędy poczty elektronicznej $\mathrm{w}$ darmowych serwisach, co świadczy o braku wiedzy o grożących niebezpieczeństwach, jak chociażby możliwości naruszenia prywatności korespondencji, braku gwarancji bezpiecznego przechowywania dokumentów (plików) dołączanych do przesyłek. Brak adresów w domenie może naruszać, wśród osób świadomych niebezpieczeństwa, zaufanie do urzędu, i skutkować niechęcią do korespondowania. W takim przypadku funkcjonalność serwisu znacznie maleje.

Badania wykazały istotną zmianę w podejściu samorządów do kanałów, które sprzyjają nawiązywaniu interakcji z użytkownikami serwisu. Portale społecznościowe zastąpiły popularne pięć lat temu fora internetowe i czaty. Dominujący wśród wszystkich rodzajów gmin jest serwis Facebook. Świadczy to również o wzroście świadomości JST o konieczności tworzenia systemów komunikacji online dostosowanych do oczekiwań internautów i sieciowych trendów.

Istotną zmianę można również dostrzec w liczbie publikowanych informacji na temat ważnych krajowych wydarzeń. Wzrost aktywności w tego rodzaju komunikacji jest znaczny w porównaniu z liczbą sprzed pięciu lat.

Wyniki badań wskazują, że zakładana hipoteza o zwiększeniu użyteczności oraz funkcjonalności serwisów internetowych samorządów potwierdziła się częściowo. Nie uległ zasadniczej zmianie model komunikacji, zwłaszcza z wykorzystaniem standardowej poczty elektronicznej. Narzędzia sprzed pięciu lat zwiększające interaktywność, takie jak fora i czaty, nie są natomiast przez urzędy rozwijane. Wyniki dowodzą, że zastępują je narzędzia online wykorzystywane przez serwisy społecznościowe. Zastosowanie tych narzędzi powinno być widoczne w witrynie. Dysponenci urzędowych stron powinni dostosować swoje kanały komunikowania, zwłaszcza prowadzenia interakcji, do obecnych trendów. Dzięki temu zwiększy się funkcjonalność serwisów i polepszy komunikacja w ramach wspólnoty oraz otoczenia zewnętrznego JST.

\section{Bibliografia}

Batorski D. (2015), Technologie i media $w$ domach i w życiu Polaków [w:] J. Czapiński, T. Panek (red.), Diagnoza Społeczna 2013. Warunki i Jakość Życia Polaków - Raport, Departament Analiz Ekonomicznych, Warszawa. 
E- administracja w oczach internautów 2014 (2014), Ministerstwo Administracji i Cyfryzacji, Warszawa, https://mac.gov.pl/files/raport_e-administracja_w_oczach_internautow_2014 z.pdf [dostęp: 1.02.2016].

Inspekcje i listy kontrolne (2016), http://hci.pjwstk.edu.pl/index.php?page=inspekcje-i-listy-kontrolne [dostęp: 1.02.2016].

Konwersja - definicja (2016), https://support.google.com/adwords/answer/6365?hl=pl\&ref_ topic=24937 [dostęp: 1.02.2016].

Kowalik K. (2010), Internet jako współczesna forma lokalnej Agory. Oficjalne witryny internetowe gmin województwa świętokrzyskiego jako miejsce realizacji obywatelskiego prawa do informacji, praca niepublikowana, WNPiSM, UW, Warszawa.

Kowalik K. (2015a), Internetowy serwis samorzadowy - ewolucja przekazu w okresie mobilnej zmiany, Acta Universitas Lodziensis Folia Litteraria Polonica, 2(28).

Kowalik K. (2015b), Samorzadowe media internetowe - uwarunkowania społeczno-prawne wdrażania wymagań WCAG 2.0. Próba diagnozy dostępności (web accessibility) $i$ użyteczności (web usability), „Studia Medioznawcze”, 2(61).

Nielsen J. (2016a), Usability 101: Introduction to Usability, https://www.nngroup.com/articles/usability-101-introduction-to-usability/ [dostęp: 2.03.2016].

Nielsen J. (2016b), Usability Heuristics for User Interface Design, https://www.nngroup.com/ articles/ten-usability-heuristics/ [dostęp: 1.02.2016].

Policies and standards (2016), http://www.hhs.gov/web/policies-and-standards/index.html [dostęp: 1.02.2016].

Porter J., Testing the Three-Click Rule, https://www.uie.com/articles/three_click_rule/ [dostęp: 10.12.2015].

Robertson J., The Three Cliks Myth, http://www.steptwo.com.au/papers/cmb_threeslicks/ [dostęp: 10.12.2015].

Rozporządzenie Ministra Spraw Wewnętrznych i Administracji z dnia 18 stycznia 2007 r. w sprawie Biuletynu Informacji Publicznej, Dz.U. 2007 Nr 10 poz. 68.

Sakowicz M. (2007), Modernizacja samorzadu terytorialnego w procesie integracji Polski z Unia Europejska, Oficyna Wydawnicza SGH, Warszawa.

Sikorski M. (2016), Funkcjonalność a użyteczność, http://hci.pjwstk.edu.pl/index. php?page=fun [dostęp: 1.09.2016].

Strzelecki Z. (red.) (2008), Gospodarka regionalna i lokalna, Wydawnictwo Naukowe PWN, Warszawa.

Supernat J. (2002), Funkcjonowanie samorzadu terytorialnego. Propozycja metodologii badań [w:] A. Błaś (red.), Studia nad samorzadem terytorialnym, Kolonia Limited, Wrocław.

Ustawa z dnia 6 września 2001 r. o dostępie do informacji publicznej, Dz.U. 2001 Nr 112 poz. 1198.

Ustawa z dnia 16 września 2011 r. o zmianie ustawy o dostępie do informacji publicznej oraz niektórych innych ustaw, Dz.U. 2011 Nr 204 poz. 1195, Dz.U. 012 poz. 473.

What \& Why of Usability (2016), http://www.usability.gov/what-and-why/index.html [dostęp: 1.02.2016]. 